Proc. Estonian Acad. Sci, Geol., 1992, 41, 1, 11-22

UDC $549.324 .31+551.733 .1(474.2)$

Toivo KALLASTE* and Eduard PUKKONEN**'

\title{
PYRITE VARIETIES IN ESTONIAN TREMADOCIAN ARGILLITE (DICTYONEMA SHALE)
}

Abstract. Estonian Tremadocian organic-rich argillite (Dictyonema shale) contains up to $20 \%$ organic matter and $4-6 \%$ pyrite. Most of the pyrite occurs in fine-dispersed form invisible with the naked eye. About $60 \%$ of the thin sandstone interlayers in argillite are cemented with pyrite (type 1), half of them are covered with a thin finegrained pyrite seam (type 2). The constitution of the latter prompted to consider its composition and genesis similar to the fine-dispersed pyrite that cannot be separated from argillite. Besides these two types, very thin $(<1 \mathrm{~mm})$ light-grey siltstone interlayers, pyrite knobs, and some pyrite findings other than the described varieties have been studied by X-ray diffractometry and emission spectroscopy methods.

\section{Introduction}

Estonian Tremadocian organic-rich argillite, traditionally known as Dictyonema shale, is distributed in North Estonia, including the northern mainland and Vormsi and Hiiumaa islands. The argillite bed with its maximum thickness of $7 \mathrm{~m}$ in the northwestern part of the mainland is thinning out southwards. Considering the lateral differences in the geochemical composition, we have suggested that three lateral zones supposedly corresponding to different sedimentation/diagenesis environments be distinguished (Пукконен, 1989; Fig. 1). For the stratigraphy, see Fig. 2.

Mineralogically, Dictyonema shale contains $30-35 \%$ illite, $25-30 \%$ K-feldspar, and $20-25 \%$ quartz; the content of organic matter reaches 20\%. Like other Early Palaeozoic black shales in the Baltoscandian region (Ándersson et al., 1985; Wilde et al., 1989), Estonian Dictyonema shale has relatively high concentrations of molybdenum (up to $1990 \mathrm{ppm}$ ), uranium (up to 1038 ppm), and vanadium (up to 1910 ppm; Пукконен, 1989). Pure argillite (without sandstone and limestone interlayers) contains usually $4-6 \%$ pyrite, mainly in fine-dispersed form invisible with the naked eye. Other, visible varieties observed are various kinds of nodules, crystal aggregates, and pyrite cement. Investigation of fine-dispersed pyrite is of practical interest for estimating its role in the self-ignition processes of Dictyonema shale removed before phosphorite mining and dumped in quarries. It is very difficult to separate fine-dispersed pyrite from argillite. Therefore, earlier studies of pyrite in argillite have dealt mainly with its visible varieties (Пылина, 1966; Лоог, 1982).

Unlike the Alum Shale sequence in Sweden, the Estonian Dictyonema shale contains several sandstone interlayers, especially in NorthEast Estonia. These sandstone interlayers are very often cemented with pyrite $(60 \%$ of the samples studied).

\footnotetext{
* Eesti Teaduste Akadeemia Geoloogia Instituut (Institute of Geology, Estonian Academy of Sciences). Estonia pst. 7, 200105 Tallinn. Estonia.
}

** Eesti Geoloogiakeskus (Geological Survey of Estonia). Piiri 5, 203053 Keila. Estonia. 


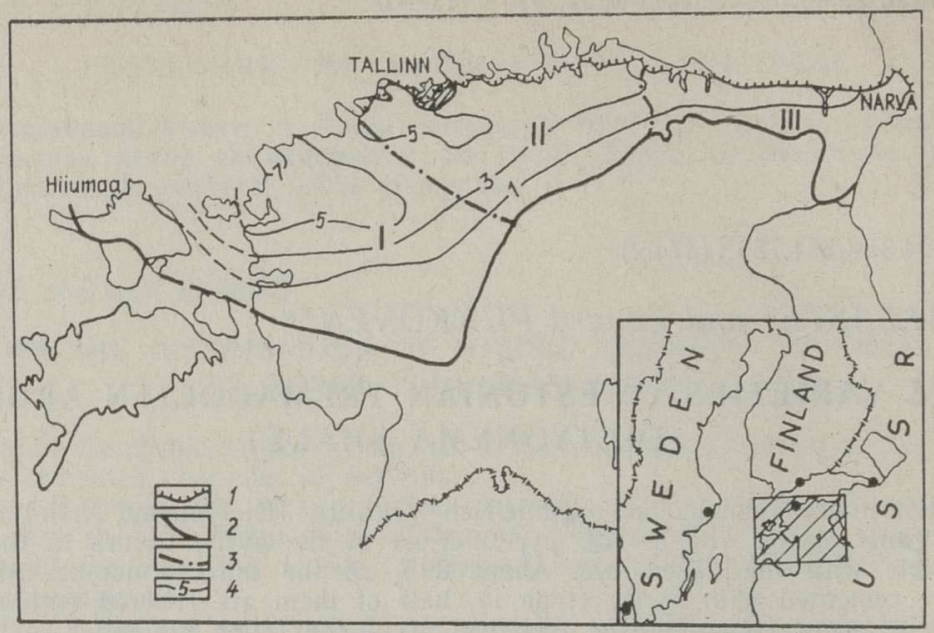

Fig. 1. Distribution of Estonian Tremadocian argillite (Dictyonema shale): 1 - klint, 2 - outthinning line of the Türisalu Formation, 3 - boundary between different geochemical zones, 4 - isopachytes (in metres).

Zones: I - West, II - Central, III - East.

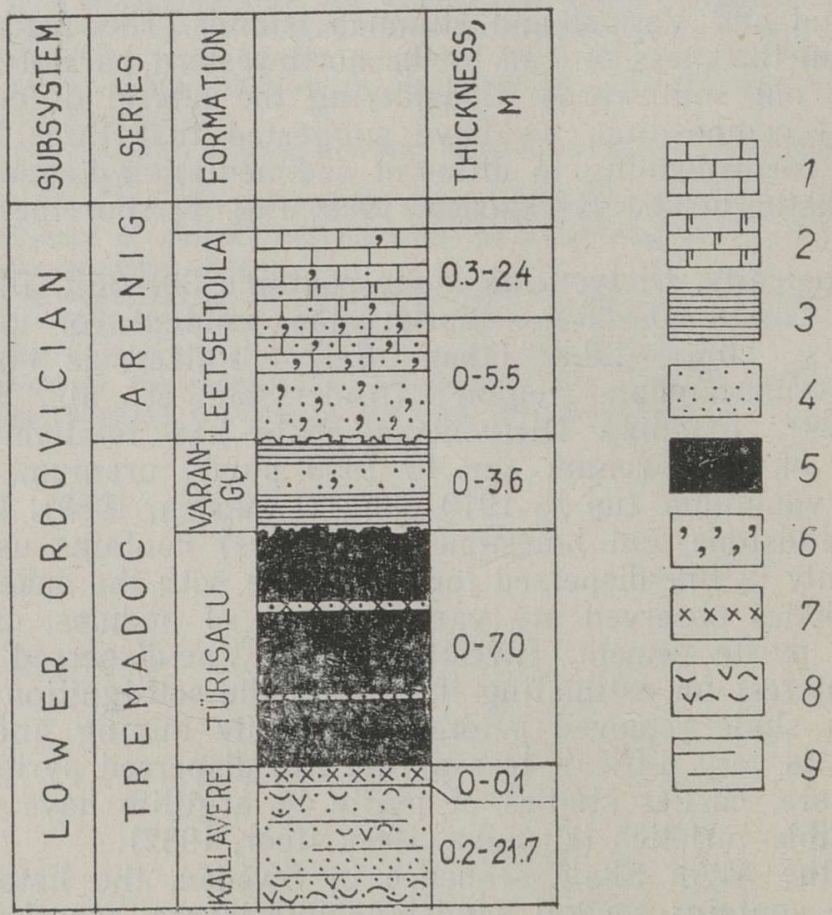

Fig. 2. Stratigraphical scheme of the Tremadocian and Arenigian rocks in North Estonia: 1 - limestone, 2 - dolomitic limestone, 3 - clay (argillite), 4 - quartzose sandstone and siltstone, 5 - organic-rich argillite (Dictyonema shale), 6 - glauconite, 7 pyrite, 8 - complete shells and debris of inarticulate brachiopods, 9 - interlayers of organic-rich argillite.

Note: Part of the Kallavere Formation belongs to the Upper Cambrian. 
The present paper provides the results of X-ray diffractometry (XRD) and emission spectroscopy analyses (ESA) of the pyritized sandstone interlayers from the Türisalu Formation and the "pyrite layer" from the uppermost part of the phosphate-bearing Obolus-sandstones of the underlying Kallavere Formation (Fig. 2).

Main attention has been paid to the pyrites cementing sandstone or siltstone interlayers (here referred to as variety 1) and to the very thin rinds of fine-crystalline pyrite on it (variety 2). The latter may represent fine-dispersed pyrite.

\section{Material and methods}

The samples were collected mainly from the drilling cores in North Estonia, and partly from outcrops (Mäekalda and Suhkrumäe) located in Tallinn. The different types of seams studied contained the respective different varieties of pyrites. Considering the source rock and the character of pyrite the following five varieties of pyrite were distinguished.

Variety 1. Sandstone or siltstone interlayers with cementing pyrite, as a rule, hard rocks with quartz/pyrite weight ratio over 0.5 (quartz predominates in volume). About half of the pyrite occurs as pore-filling cement and another half as basal cement. About $40 \%$ of the samples were collected from the "pyrite layer" of the Kallavere Formation with the thickness reaching up to $15 \mathrm{~cm}$. The rest of the samples were collected from thin (up to $2 \mathrm{~cm}$ thick) sandy interlayers occurring in the overlaying Dictyonema shale.

Variety 2. About half of the above-mentioned pyritized layers (variety 1) were covered with a very thin (up to $1 \mathrm{~mm}$ thick) siltstone or clay seam containing a large percentage of invisible pyrite. Unlike the layers of the source rock of variety 1 , they were more friable and the samples collected from the core were covered with a thin rind of iron sulphate. Inside these seams, we could often observe microlayers which might be attributed to the sulphate-forming process leading to the separation of individual flamellae (seams). The quartz/pyrite (weight) ratio in the layers of the source rock of variety 2 did not exceed 0.1 .

Additionally, some cores and the Mäekalda outcrop were examined to find individual seams containing variety 2 which were not in contact with the layers containing variety 1 . Some seams found are referred to as variety $2 \mathrm{a}$.

In order to examine the non-sulphide composition of the seams containing variety 2 , ten samples were treated with $10 \mathrm{~N} \mathrm{HNO}_{3}$ for 48 hours. The major components in the insoluble residue proved to be quartz, orthoclase, illite, and organic matter. To determine the quartz/orthoclase ratio, the calibration coefficient was taken into account. The amount of organic matter in the insoluble residue was determined by heating the residue at $550^{\circ} \mathrm{C}$. Illite concentration was qualitatively estimated by reflection $4.5 \AA$.

Variety 3 occurs in some individual very thin (up to $1 \mathrm{~mm}$ ) weakly pyritized siltstone seams. These light-grey seams, containing less than $50 \%$ pyrite, occur mainly in the thick homogeneous Dictyonema shale layers in the northwestern part of Estonia. One sample of very thin $(<1 \mathrm{~mm})$ pyrite lens inside this siltstone seam is here referred to as variety $3 a$.

Variety 4 occurring in the same type of rocks as variety 2 includes pyrite aggregates (knobs) with the height up to $1 \mathrm{~mm}$ and width up to $2 \mathrm{~mm}$. Variety 4 differs from variety 2 also in crystal structure. 
Table 1

Results of the X-ray diffractometry and emission spectroscopy analyses of the pyritized sandstone (siltstone) seams

\begin{tabular}{|c|c|c|c|c|c|c|c|c|c|c|c|c|c|c|}
\hline No. Sample & Var. & F Zone & a & $b$ & Q $/ m+P y$ & $M / M+P y$ & Co & $\mathrm{Ni}$ & $\mathrm{Cu} P \mathrm{~Pb}$ & In & Mo & As & $\mathrm{Ag}$ & Suppleaents \\
\hline 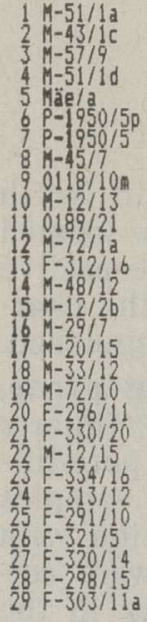 & & & 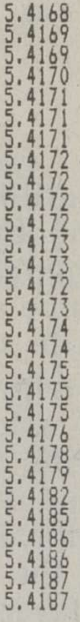 & $\begin{array}{l}0.08 \\
0.10 \\
0.06 \\
0.13 \\
0.14 \\
0.17 \\
0.18 \\
0.19 \\
0.10 \\
0.08 \\
0.12 \\
0.04 \\
0.12 \\
0.10 \\
0.16 \\
0.13 \\
0.26 \\
0.12 \\
0.10 \\
0.10 \\
0.12 \\
0.26 \\
0.13 \\
0.13 \\
0.23 \\
0.22 \\
0.25\end{array}$ & $\begin{array}{l}0.80 \\
0.78 \\
0.26 \\
1.50 \\
1.08 \\
0.55 \\
0.48 \\
0.53 \\
1.57 \\
1.55 \\
1.03 \\
0.52 \\
0.65 \\
0.39 \\
0.64 \\
1.10 \\
0.80 \\
0.91 \\
0.89 \\
2.14 \\
0.51 \\
1.43 \\
1.00 \\
1.79 \\
1.34 \\
0.12\end{array}$ & $\begin{array}{r}22 \\
22 \\
4 \\
12 \\
12\end{array}$ & $\begin{array}{r}4 \\
4 \\
6 \\
2 \\
? \\
4 \\
9 \\
6 \\
4 \\
6 \\
5 \\
3 \\
4 \\
8 \\
6 \\
7 \\
15 \\
6 \\
10 \\
8 \\
6 \\
8 \\
6 \\
4 \\
6\end{array}$ & $\begin{array}{l}150 \\
80 \\
70 \\
27 \\
50 \\
50 \\
90 \\
80 \\
80 \\
50 \\
220 \\
120 \\
60 \\
90 \\
100 \\
70 \\
150 \\
550 \\
60 \\
350 \\
280 \\
400 \\
600 \\
250 \\
80 \\
370\end{array}$ & 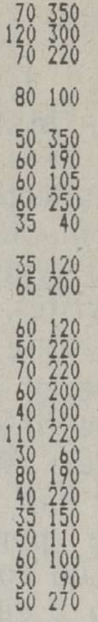 & $\begin{array}{r}20 \\
0 \\
0 \\
1001 \\
0 \\
0 \\
0 \\
0 \\
30 \\
0 \\
0 \\
80 \\
40 \\
0 \\
0 \\
0 \\
40 \\
0 \\
0 \\
320 \\
0 \\
40\end{array}$ & $\begin{array}{r}60 \\
150 \\
35 \\
17 \\
1180 \\
40 \\
10 \\
60 \\
20 \\
80 \\
440 \\
20 \\
50 \\
140 \\
270 \\
120 \\
30 \\
35 \\
140 \\
170 \\
25 \\
270 \\
570 \\
35 \\
25\end{array}$ & $\begin{array}{c}50 \\
150 \\
140 \\
140 \\
400 \\
100 \\
10 \\
270 \\
380 \\
60 \\
140 \\
170 \\
240 \\
300 \\
100 \\
350 \\
240 \\
570 \\
200 \\
100 \\
1000\end{array}$ & $\begin{array}{l}0.30 \\
0.60 \\
0.40 \\
0.40 \\
0.40 \\
1.00 \\
0.60 \\
0.60 \\
0.40 \\
0.60 \\
0.60 \\
0.30 \\
0.80 \\
0.80 \\
1.00 \\
1.00 \\
1.00 \\
0.60 \\
1.00 \\
0.80 \\
1.00 \\
0.50 \\
0.60 \\
0.60 \\
0.90\end{array}$ & $\begin{array}{l}\text { calcite } \\
\text { calcite } \\
\text { dolonit } \\
\text { calcite } \\
\text { calcite } \\
\text { calcite }\end{array}$ \\
\hline 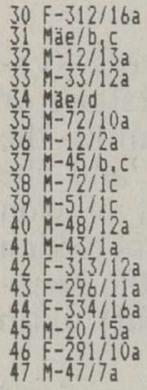 & & & $\begin{array}{l}5.4168 \\
5: 4.68 \\
5: 469 \\
5.469 \\
5: 410 \\
5: 470 \\
5: 4171 \\
5: 471 \\
5: 4172 \\
5: 4172 \\
5: 473 \\
5: 4173 \\
5: 4177 \\
5.479 \\
5.4187 \\
5.4200\end{array}$ & $\begin{array}{l}0.10 \\
0.12 \\
0.52 \\
0.31 \\
0.08 \\
0.11 \\
0.07 \\
0.17 \\
0.15 \\
0.22 \\
0.08 \\
0.13 \\
0.11 \\
0.12 \\
0.17 \\
0.14 \\
0.31\end{array}$ & $\begin{array}{l}0.07 \\
0.02 \\
0.01 \\
0.11 \\
0.04 \\
0.07 \\
0.10 \\
0.03 \\
0.02 \\
0.02 \\
0.04 \\
0.03 \\
0.11 \\
0.03 \\
0.01 \\
0.02 \\
0.03\end{array}$ & $\begin{array}{r}0 \\
15 \\
2 \\
0\end{array}$ & $\begin{array}{c}9 \\
15 \\
15 \\
6 \\
5 \\
12\end{array}$ & $\begin{array}{l}2001 \\
\\
22 \\
3001 \\
801 \\
170 \\
3501 \\
90\end{array}$ & 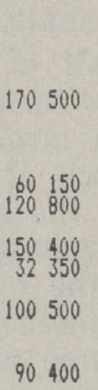 & $\begin{array}{l}20 \\
00 \\
60 \\
20 \\
0 \\
20 \\
60\end{array}$ & $\begin{array}{r}17 \\
220 \\
17 \\
25 \\
200 \\
100 \\
20\end{array}$ & $\begin{array}{l}400 \\
100 \\
220 \\
100 \\
50 \\
150 \\
170\end{array}$ & $\begin{array}{l}0.50 \\
0.40 \\
0.50 \\
0.50 \\
0.30 \\
0.60 \\
0.50\end{array}$ & \\
\hline $\begin{array}{l}48 \mathrm{Mae} / 1 \mathrm{~b} \\
49 \mathrm{Mae} / \mathrm{da} \\
50 \mathrm{M-12/1} \\
51 \mathrm{Mae} / \mathrm{c}\end{array}$ & $\begin{array}{l}2 a \\
2 a \\
2 a \\
2 a\end{array}$ & & $\begin{array}{l}5.4169 \\
5.4170 \\
5: 4171 \\
5.4173\end{array}$ & $\begin{array}{l}0.10 \\
0.26 \\
0.15 \\
0.31\end{array}$ & $\begin{array}{l}0.05 \\
0.07 \\
0.14 \\
0.09\end{array}$ & 8 & ? & $\begin{array}{l}200 \\
100\end{array}$ & $\begin{array}{l}60500 \\
80270\end{array}$ & $\begin{array}{l}40 \\
20\end{array}$ & $\begin{array}{l}20 \\
60\end{array}$ & $\begin{array}{r}200 \\
50\end{array}$ & 0.40 & \\
\hline $\begin{array}{ll}52 & F-339 / 1 \\
53 & F-343 / 2 b \\
54 & F-343 / 3 b \\
55 & m-43 / 2 a \\
56 & F-343 / 2 a\end{array}$ & $3 a$ & & $\begin{array}{l}5.4180 \\
5.4180 \\
5.4191 \\
5.494 \\
5.4224\end{array}$ & $\begin{array}{l}0.14 \\
0.22 \\
0.22 \\
0.21 \\
0.39\end{array}$ & $\begin{array}{l}0.91 \\
0.61 \\
0.45 \\
0.36 \\
0.07\end{array}$ & $\begin{array}{l}0 \\
8 \\
8\end{array}$ & $\begin{array}{r}50 \\
12 \\
30 \\
170\end{array}$ & $\begin{array}{l}600 \\
250 \frac{1}{400} \\
4000 \frac{2}{3}\end{array}$ & $\begin{array}{rl}90 & 250 \\
100220 \\
200 \\
350 & 350 \\
350\end{array}$ & $\begin{array}{l}20 \\
30 \\
20 \\
20\end{array}$ & $\begin{array}{r}80 \\
100 \\
150 \\
170\end{array}$ & $\begin{array}{r}250 \\
250 \\
100 \\
1000\end{array}$ & $\begin{array}{l}2.00 \\
3.00 \\
0.80 \\
3.00\end{array}$ & \\
\hline $\begin{array}{l}57 \mathrm{M-51/1 \textrm {b }} \\
5 \mathrm{~K} \mathrm{Ma} / \mathrm{e} \\
59 \mathrm{~F}-303 / 11 \mathrm{~b}\end{array}$ & 4 & & $\begin{array}{l}5.4173 \\
5.4179\end{array}$ & $\begin{array}{l}0.32 \\
0.28\end{array}$ & $\begin{array}{l}0.02 \\
0.02 \\
0.06\end{array}$ & $\frac{11}{54}$ & 5 & 200 & 60500 & 0 & 27 & 250 & 0.40 & \\
\hline 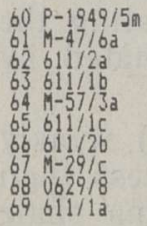 & $\begin{array}{l}5 \\
5 \\
5 \\
5\end{array}$ & & $\begin{array}{l}5.4172 \\
5: 4174 \\
5.476 \\
5: 4177 \\
5.4799 \\
5.479 \\
5.4182 \\
5.484 \\
5.4192 \\
5.4196\end{array}$ & $\begin{array}{l}0.39 \\
0.17 \\
0.24 \\
0.17 \\
0.21 \\
0.30 \\
0.21 \\
0.21 \\
0.18 \\
0.31\end{array}$ & $\begin{array}{l}0.37 \\
0.02 \\
? .13 \\
0.02 \\
0.02 \\
0.03 \\
0.05 \\
0.02 \\
0.03 \\
0.03\end{array}$ & 8 & & & & & & & & \\
\hline
\end{tabular}

Var.- variety ; F - Formations: T - Jdrisalu; K-Kallavere. Zones: 1 - West; II - Central; III - Eaşt.

- the lattice parameter of pyrite, A: b - the reflection widening (crystallinity) of pyrite ( 2 \& degroas O- quartzi M- marcasite; Py - pyrite. 
Variety 5 includes other types of pyrite: pyrite nodules, fissure fillings, and little veins were observed.

X-ray diffractometry. Using X-ray diffractometer. DRON-2, relations between pyrite, marcasite, and quartz, the lattice parameters, and the widening of the pyrite reflections (crystallinity) were determined. The pyrite reflection [520] was studied using an approximation method described in (Калласте, 1990), adding one function characterizing the background signal. The following empirical approximation formula was used:

$$
D(x)=c+f_{1}(x)+0.5 \cdot 1.03 \cdot f_{1}\left(x^{\prime}\right)+f_{2}(x),
$$

where $c$ is background level, $f_{1}(x)$ is $K_{\alpha 1}$-line, $0.5 \cdot f_{1}\left(x^{\prime}\right)$ is $K_{\alpha 2}$-line (constant 1.03 was used in order to take into account the polarization and Lorentz factors), $f_{2}(x)$ describes the nonlinearity of the background.

The functions $f_{1}(x)$ and $f_{2}(x)$ are asymmetrical bell-shaped functions:

$$
\begin{gathered}
f_{1}(x)=a \cdot\left[1+w_{0}\left(x-x_{0}\right)^{2}\right]^{-b} \cdot\left[1+w_{1} \cdot\left(x-x_{0}\right)\right], \\
f_{2}(x)=d \cdot\left[1+e_{0}\left(x-x_{1}\right)^{2}\right]^{-1} \cdot\left[1+e_{1} \cdot\left(x-x_{1}\right)\right],
\end{gathered}
$$

where $a, w_{0}, x_{0}, b, w_{1}, d, e_{0}, x_{1}, e_{1}$ are variable parameters.

The new formula considering the background nonlinearity gave significantly better approximations. Nevertheless, we could not reliably segregate the background nonlinearity from the reflection. Therefore, the centre of gravity of the reflection and the integral half-width were calculated presuming a linear background (according to the reflection plus the nonlinear component of the background signal). The lattice parameter $a$ was calculated from the centre of gravity of the reflection.

Emission spectroscopy analysis was carried out in the laboratory of the Geological Survey of Estonia. Altogether 44 samples of variety 1, 9 samples of varieties 2 and $2 \mathrm{a}$, and 3 samples of variety 3 were analysed. The analyses of all the 44 samples of variety 1 were used for calculating the mean concentrations and in correlation analyses. Table 1 presents the ESA results for 25 individual samples also analysed by XRD.

Only the data of the eight minor elements related mainly to the sulphide minerals are shown here. Their detection limits were as follows $(\mathrm{ppm})$ : $\mathrm{Co}-1, \mathrm{Ni}-1, \mathrm{Cu}-3, \mathrm{~Pb}-10, \mathrm{Zn}-10, \mathrm{Mo}-1, \mathrm{As}-100$, $\mathrm{Ag}-0.1$. The concentration of $50 \mathrm{ppm}$. As presented means traces in the sample, $10 \mathrm{ppm}$ - no As was detected. All the samples were burned two (if needed, three) times and the arithmetical mean of the estimated contents was calculated. After the burning of every 5 samples, a laboratory pyrite standard E-97 was used to graduate spectrum lines. Although the ESA applied here is not a precise quantitative method, it gave some preliminary information on the behaviour of minor elements useful for future studies.

\section{Results}

The results of XRD and ESA for the five varieties studied are given in Table 1, where the samples are arranged in the ascending order of the lattice parameter $a$. Interpretation of these data is presented as the following characterization of the varieties.

Variety 1 (sandstone interlayers cemented by pyrite). The major mineral constituents are pyrite and quartz. Marcasite occurs often (in 
$60 \%$ of the samples), but only in small quantities. Orthoclase/quartz ratio does not usually exceed 1:10 (a semiquantitative estimation). In some cases almost pure quartzose sand is cemented by iron sulphide. In some samples, calcite, dolomite, francolite, sphalerite, and galena were detected.

Results of the measurements of the pyrite lattice parameter and the reflection [520] are shown in Fig. 3. Most of the samples of variety 1 pyrites have a normal lattice parameter $a$ (average $5.4176 \AA$ ). However, a group of samples having a bigger lattice parameter can be clearly separated (Fig. 3, variety 1). These samples originate mostly from the drilling cores of North-West Estonia.

The reflection widening of variety 1 pyrite is small to normal; the bigger values are related to the growth of the lattice parameter. Pyrites with low crystallinity have not been found.

Variety 1

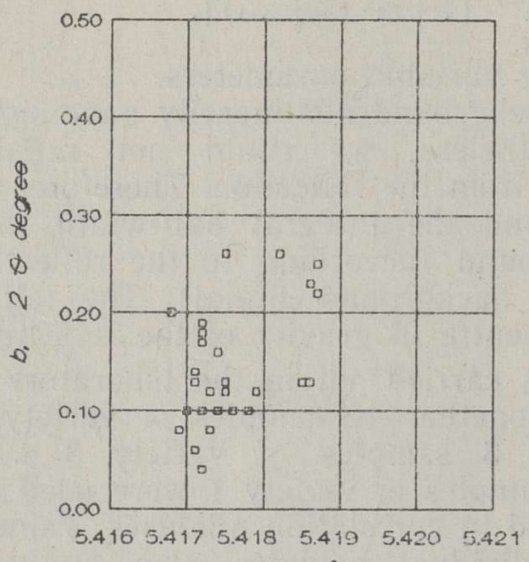

a. $\AA$

Varieties $3 \& 4$

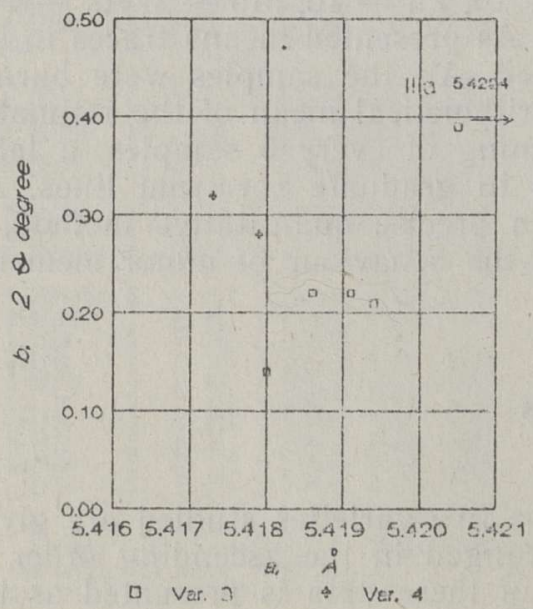

Variety 2

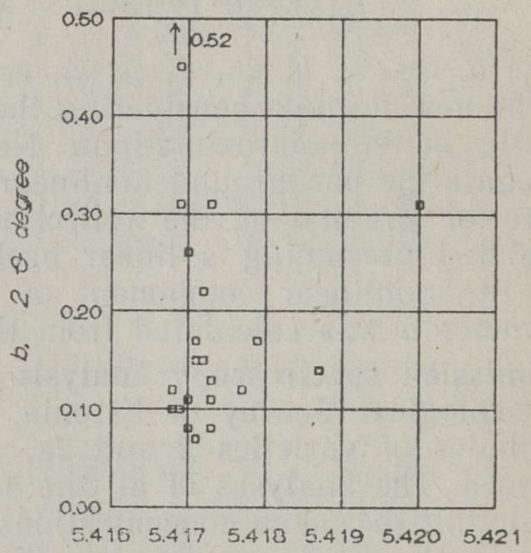

a, $\AA$.

Variety 5

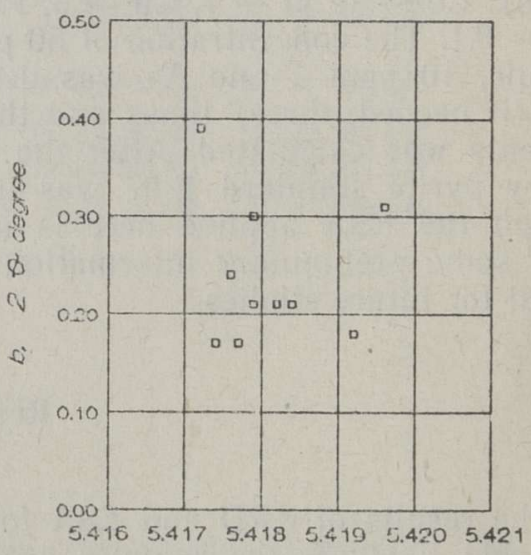

a. $\AA$

Fig. 3. The lattice parameter (a) versus the reflection widening (crystallinity) $(b)$ in the different varieties of pyrite. 
Variety 2 (thin layers of pyrite). When the quartz/pyrite (weight) ratio was 0.02 , then $87 \%$ of the sample dissolved in $\mathrm{HNO}_{3}$ (the dissolved amount corresponded to the approximate amount of pyrite). When the ratio was 0.14 , the dissolved amount was $61 \%$. Of the analysed samples 21 lied within this range. Five samples of argillite, containing $10-40 \%$ pyrite are considered to be transitional varieties occurring in pyritized layers associated with variety 2 and argillite. As compared to variety 1 , less marcasite was determined in variety 2 . Fig. 3 shows that the majority of the samples like variety 1 are characterized by a normal lattice parameter and. a small reflection widening (respectively $520,<0.22 \theta$ degrees); the share of pyrites with an enlarged lattice parameter is negligible. Still, unlike in case of the pyrites of variety 1 , a group of pyrites with a wider reflection and a normal lattice parameter was found.

After treating it with $\mathrm{HNO}_{3}$, the residue of the samples of variety 2 consisted mainly of brown lamellae of organic matter. Usually silty grains were stuck to these lamellae.

Frequent sand grains suggest that variety 2 is associated with sandier rocks. The orthoclase/quartz (Ort/Q) ratio of the insoluble residues ranged from 1.1 to 2.6 ; in argillite the ratio was 1.5 to 1.8 and in unpyritized silty seams 1.1 to 1.2 .

The heating losses of the insoluble residues, indicating their approximate organic matter content, ranged from $8 \%$ to $36 \%$ (in raw argillite from $18 \%$ to $26 \%$ ). Data on the heating losses showed a positive correlation with Ort/Q ratio. The illite content of the insoluble residue was generally the same as in argillite. Slightly higher concentration was observed in the layer with the thickness $5 \mathrm{~mm}$ yielding variety 2 and overlaying the "pyrite layer" of the Kallavere Formation in the Mäekalda outcrop.

The boundary between the Türisalu and Kallavere formations was examined also in the Suhkrumäe outcrop, where variety 1 had been weathered and transformed into brown amorphous iron oxides. Between the argillite layer and the sandstone layer, an up to $5 \mathrm{~cm}$ thick zone composed of the intercalations of yellow jarosite seams and argillite occurred. Therefore, different pyrite types had different hypergenesis processes: on the one hand a quick formation of iron oxides, on the other, the occurrence of a distinct sulphate interstage.

Table 2

Average results of the X-ray diffractometry and emission spectroscopy analyses of different pyritized samples

\begin{tabular}{|c|c|c|c|c|c|c|c|c|c|c|c|c|c|c|c|}
\hline Var. & lone & $n$ & a & b & $0 / M+P y$ & $M / M+P y$ & $n$ & co & $\mathrm{Ni}$ & $\mathrm{Cu}$ & $\mathrm{Fb}$ & $\ln 1$ & Mo & As & $\mathrm{Ag}$ \\
\hline 1 & II & $\begin{array}{r}9 \\
20 \\
29\end{array}$ & $\begin{array}{l}5.4182 \\
5.4172 \\
5.4176\end{array}$ & $\begin{array}{l}0.17 \\
0.13 \\
0.14\end{array}$ & $\begin{array}{l}0.82 \\
0.82 \\
0.82\end{array}$ & $\begin{array}{l}3 \\
3 \\
3\end{array}$ & $\begin{array}{l}19 \\
27 \\
46\end{array}$ & $\begin{array}{l}7 \\
6 \\
7\end{array}$ & $\begin{array}{l}330 \\
120 \\
210\end{array}$ & $\begin{array}{l}55 \\
58 \\
57\end{array}$ & $\begin{array}{l}200 \\
170 \\
190\end{array}$ & $\begin{array}{r}50 \\
8 \\
30\end{array}$ & $\begin{array}{l}130 \\
100 \\
115\end{array}$ & $\begin{array}{l}330 \\
170 \\
240\end{array}$ & $\begin{array}{l}1.0 \\
0.6 \\
0.8\end{array}$ \\
\hline $\begin{array}{l}2 \\
2 \\
2\end{array}$ & II & $\begin{array}{r}4 \\
18 \\
22\end{array}$ & $\begin{array}{l}5.4180 \\
5.4172 \\
5.4174\end{array}$ & $\begin{array}{l}0.17 \\
0.18 \\
0.18\end{array}$ & $\begin{array}{l}0.06 \\
0.05 \\
0.05\end{array}$ & $\begin{array}{l}4 \\
0 \\
1\end{array}$ & $\begin{array}{l}2 \\
7 \\
9\end{array}$ & $\begin{array}{l}9 \\
8 \\
8\end{array}$ & $\begin{array}{l}260 \\
140 \\
170\end{array}$ & $\begin{array}{r}66 \\
104 \\
96\end{array}$ & $\begin{array}{l}430 \\
430 \\
430\end{array}$ & $\begin{array}{l}10 \\
30 \\
30\end{array}$ & $\begin{array}{r}150 \\
54 \\
75\end{array}$ & $\begin{array}{l}100 \\
180 \\
160\end{array}$ & $\begin{array}{l}0.5 \\
0.5 \\
0.5\end{array}$ \\
\hline $\begin{array}{l}3 \\
3 a \\
4 \\
5\end{array}$ & & $\begin{array}{r}4 \\
1 \\
3 \\
10\end{array}$ & $\begin{array}{l}5.4188 \\
5.4224 \\
5.4176 \\
5.4181\end{array}$ & $\begin{array}{l}0.20 \\
0.39 \\
0.30 \\
0.24\end{array}$ & $\begin{array}{l}0.58 \\
0.07 \\
0.03 \\
0.07\end{array}$ & $\begin{array}{r}0 \\
0 \\
22 \\
2\end{array}$ & $\begin{array}{l}3 \\
1 \\
1\end{array}$ & $\begin{array}{r}31 \\
170 \\
5\end{array}$ & $\begin{array}{r}420 \\
4000 \\
200\end{array}$ & $\begin{array}{r}130 \\
350 \\
60\end{array}$ & $\begin{array}{l}210 \\
350 \\
500\end{array}$ & $\begin{array}{r}20 \\
20 \\
0\end{array}$ & $\begin{array}{r}110 \\
170 \\
27\end{array}$ & $\begin{array}{r}200 \\
1000 \\
250\end{array}$ & $\begin{array}{l}1.9 \\
3.0 \\
0.4\end{array}$ \\
\hline
\end{tabular}

Legend see Table : 
As shown in Table 2, pyrite varieties 1 and 2 have different compositions of minor elements: variety 2 shows a higher $\mathrm{Pb}$ content, but lower $\mathrm{Mo}$ and $\mathrm{As}$ contents. The concentration of $-\mathrm{Ni}$ is higher in the pyritized seams belonging to the western sections of the Dictyonema shales (zone I, Figs. 1, 4) and lower in the central part (zone II, Figs. $1,4)$, although its concentration in the argillite surrounding these seams is similar. Such a difference is thought to be the result of the different $\mathrm{Ni}$ productivity of the western and central zones of the Türisalu Formation (91 ppm with average thickness of $4.5 \mathrm{~m}$ and $75 \mathrm{ppm}$ in $3.2 \mathrm{~m}$, respectively).

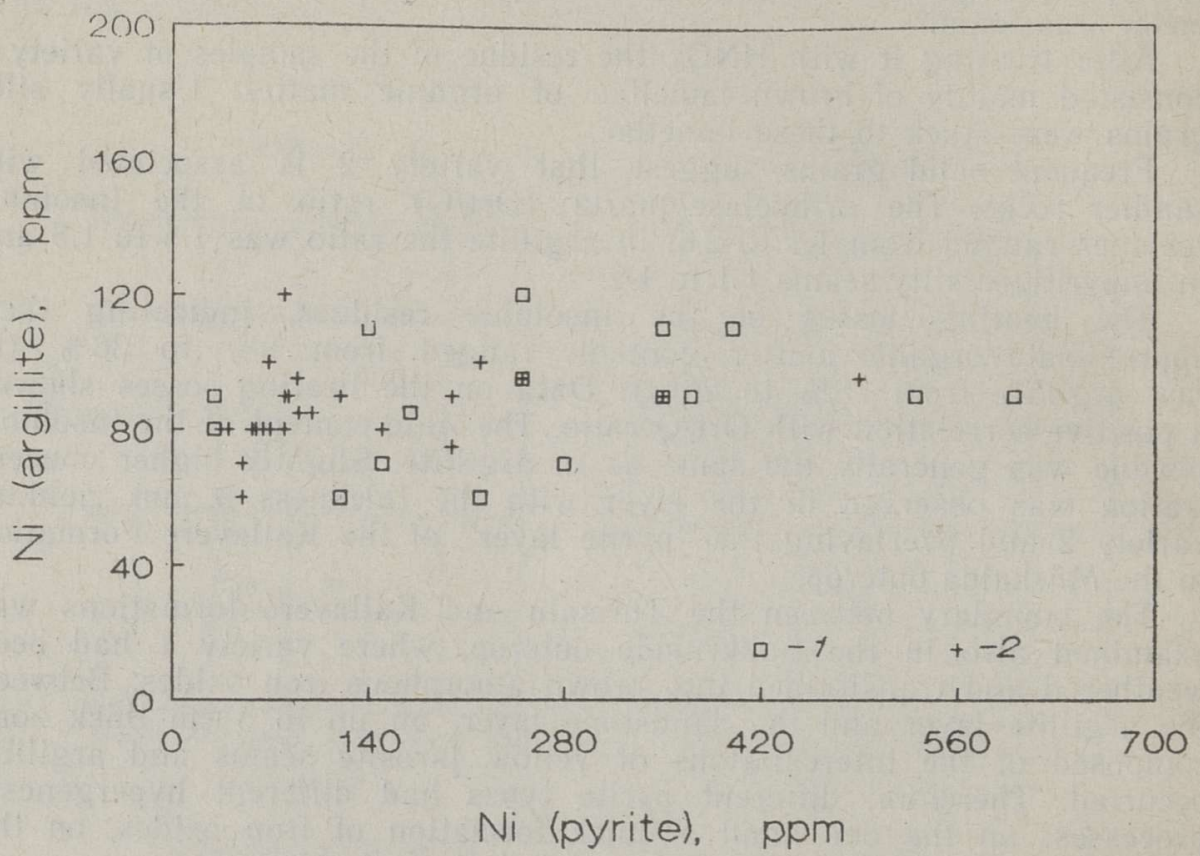

Fig. 4. $\mathrm{Ni}$ in pyrite versus $\mathrm{Ni}$ in the surrounding argillite: 1 - zone I (West); 2 - zone II (Central).

The nine samples of variety 2 analysed indicated a positive correlation between $\mathrm{Ni}, \mathrm{Co}$, and $\mathrm{Pb}$ : for $\mathrm{Ni}$ and $\mathrm{Co} r=0.85$; for $\mathrm{Co}$ and $\mathrm{Pb}$ $r=0.87$; for $\mathrm{Ni}$ and $\mathrm{Pb} r=0.78$. The 44 samples of variety 1 showed positive, but weak correlation between $\mathrm{Ni}$ and $\mathrm{Ag}(r=0.62), \mathrm{Ni}$ and $\mathrm{As}$ (0.53), As and $\mathrm{Ag}(0.49)$. In addition, a weak correlation existed between marcasite and iron sulphide (iron sulphide $=$ marcasite + pyrite) ratio and Ni: for variety 2, $r=0.70(n=8)$; for variety $1, r=0.46 \quad(n=22)$.

Variety 3 originating from partly pyritized, very thin siltstone seams; had an enlarged lattice parameter of pyrite (see Fig. 3). Marcasite did not occur. As compared to varieties 1 and 2, higher concentration of the typical isomorphous elements in pyrite $(\mathrm{Ni}, \mathrm{Co})$ was determined (see Table 2).

The maximum lattice parameter $(5.4224 \AA)$ was determined in the pyrite lens with the thickness of $1 \mathrm{~mm}$ formed in the seam yielding variety 3 and having extremely high concentrations of $\mathrm{Ni}(4000 \mathrm{ppm})$ and Co $(170 \mathrm{ppm})$ (see Table 2, IIIa). Formations like this need further investigation. 
Variety 4. Knobs on the pyritized seams yielding variety 2. All the samples contained marcasite, but in different amounts. Pyrite reflection had widened to some extent (Fig. 3).

Variety 5. All the pyrite findings except the four above-described varieties. These were quite pure pyrites with a widened lattice parameter (Fig. 3).

\section{Discussion}

About $60 \%$ of the sandstone interlayers in the Tremadocian argillite (Dictyonema shale) examined are cemented with pyrite. Half of them are covered with a thin fine-grained pyrite seam yielding variety 2 pyrite. This variety is interesting in several aspects. Its fine-grained constitution is similar to the fine-dispersed pyrite in argillite. A similar genesis is expected because of the closeness of the nonsulphide composition of the seam yielding variety 2 and argillite. The samples of argillite with higher concentration of pyrite fitted the transitional nature of the seams containing variety 2 between argillite and the sandy interlayers containing variety 1.

On the other hand, genetic ties between seams yielding varieties 1 and 2 are of interest. Variety 1 pyrite, cementing the sandstone interlayer, formed probably from the solution derived from the overlaying mud deposit, where intensive sulphate reduction took place. Therefore, the mud layer behaved as an intermediary in the deposition of iron and sulphur (derived from sea water) into the pores of the underlaying sandy layer. The variety 2 fine-crystalline pyrite formed probably as a result of the compaction of sulphur-rich mud. In this sulphide-rich seam, somewhat more anomalous conditions existed than in the argillite formation. A discrete transition from the pyritized layer yielding variety 2 toward argillite corresponds to changes in the deposition environment. The high Ort/Q ratio of this type of seams, exceeding the ratio in the argillite also refers to anomalous conditions and formation of authigenic feldspar.

The model described indicates an early formation of pyrite of varieties 1 and 2. It is logical to consider that the "pyrite layer" distributed between the Kallavere and Türisalu formations has been formed as a result of the influence of overlaying deposits and before these deposits reached impermeability, hence, in the stage of late diagenetic litification. The sand lenses inside argillite underwent probably the same changes but to a smaller extent.

The subsequent sulphide-forming process remains a problem. Probably, the findings of sphalerite and galena and the more frequent occurrence of marcasite as well as the enlarged lattice parameter of pyrite give evidence of later processes. This conclusion is supported by the investigations carried out on Cambrian iron sulphides, where no enlarged lattice parameter and marcasite supplements in diagenetic pyrites were found (Калласте, 1990). However, we must take into account the great difference of the Tremadocian and Cambrian pyrites.

The pyrite knobs (variety 4 ) on the seams yielding variety 2 have probably been formed later than the latter. The marcasite content and quite low crystallinity of the knobs prompted to consider their primarily marcasite formation.

Experience gathered in the field of Cambrian pyrites has shown that marcasite formation was related mainly to the so-called "superposed" processes (Пиррус, 1981). 
Differences in the concentrations of $M o$ and As between the seams yielding varieties 1 and 2 (Table 2) are of interest. Higher concentrations of $\mathrm{Mo}$ and As are attributed to the ability of euhedral pyrite to incorporate them (Raiswell and Plant, 1980; Raiswell, 1982). It confirms the conclusion that pyrite of variety 1 in sandy layers formed a little later than in the seam covering it and yielding variety 2 , because the pyrite crystals that formed in the sandy layers grew bigger (using free pore space) and, hence, their growth was slower, resulting in the formation of euhedral pyrite.

\section{Conclusions}

The study of pyritized sandstone (siltstone) interlayers (yielding pyrite of variety 1) in the Dictyonema shale showed that these interlayers were overlain by very thin fine-crystalline pyrite seams (yielding variety 2). The composition of the insoluble residue and the fine-crystalline background of the seam yielding variety 2 prompted to consider its similar genesis with the fine-dispersed pyrite from argillite. Although argillite contains a great amount of fine-dispersed pyrite $(4-6 \%)$, it is very difficult to separate them. But fine-dispersed pyrite plays an important role in the process of self-ignition of Dictyonema shale in the Maardu phosphorite quarry. The two types can be characterized as follows:

Type 1 - (1) Quartz/pyrite (weight) ratio exceeds 0.5 .

(2) Orthoclase/quartz ratio was probably smaller than 0.1 .

(3) The lattice parameter is usually normal ( $a=5.4176 \AA$ ) and the widening of the pyrite reflection (crystallinity) is small ( $b=0.142 \theta$ degrees). The samples from the western cores collected showed a little higher values of $a$ and $b$.

(4) Somewhat higher concentrations of $M o$ and As than in variety 2 .

(5) Weak positive correlations between $\mathrm{Ni}, \mathrm{Ag}$, and $\mathrm{As}$.

(6) In the outcrop brown iron oxide from this pyritized layer was formed due to the weathering.

Type 2 - (1) Quartz/pyrite ratio up to 0.14 .

(2) Orthoclase/quartz ratio ranged from 1.2 to 2.6.

(3) Concentration of organic matter (the heating loss) in the insoluble residue ranges from $8 \%$ to $36 \%$.

(4) The lattice parameter is also normal ( $a=5.4174 \AA$ ) and the widening of the reflection is small $(b=0.18)$. The share of the pyrites with enlarged lattice parameter was negligible.

(5) Conspicuous for its high concentration of $\mathrm{Pb}$.

(6) Positive correlation between $\mathrm{Ni}, \mathrm{Co}$, and $\mathrm{Pb}$.

(7) In the process of weathering white iron sulphate and yellowish jarosite formed.

Besides these two types very thin $(<1 \mathrm{~mm})$ light-grey siltstone interlayers in argillite (mainly in the western sections) and pyrite knobs overlaying the seams yielding variety 2 were studied. The seams containing pyrite knobs referred to as variety 3 , contain usually up to $50 \%$ of pyrite and are characterized by an enlarged lattice parameter $(\alpha=5.4188 \AA)$, the widened reflection of the pyrite $(b=0.20)$, and a large amount of the minor elements $(\mathrm{Ni}, \mathrm{Co}, \mathrm{As}, \mathrm{Cu})$. One sample $(\mathrm{F}-343 / 2 \mathrm{a})$ contained $4000 \mathrm{ppm}$ of $\mathrm{Ni}$ and $170 \mathrm{ppm} \mathrm{Co}$ and had also an enlarged lattice parameter $(a=5,4224 \AA)$ and a reflection widening 
$(b=0.39)$ of pyrite. The pyrite knobs (variety 4$)$ included more marcasite than the other varieties and their reflection was slightly widened $(b=0.30)$.

The fine-crystalline pyrite of variety 2 formed during the lithification of sulphur-rich mud under somewhat more anomalous conditions than argillite. The increased orthoclase/quartz ratio in this seam as compared to argillite testifies to the formation of authigenic K-feldspar. Pyrite of variety 1 formed a little later from interstitial waters. The peculiar higher concentrations of the minor elements in the seams containing variety 3 need further investigation. The pyrite knobs of variety 4 formed primarily as marcasite.

Acknowledgements. We wish to thank Dr. E. Pirrus for critical reading of earlier drafts of the manuscript and for his interest in the study. We are grateful to Mr. I. Puura, who thoroughly improved the English manuscript. Many thanks are due to Ms. M. Aibast for preparing the figures.

\section{REF E REN CES}

Andersson, A., Dahlman, B., Gee, G. D., and Snäll, S. 1985. The Scandinavian Alum Shales. - Sver. Geol. Unders. Ca 56.

Raiswell, R. 1982. Pyrite texture, isotopic composition and the availability of iron. Amer. J. Sci., 282, 1244-1263.

Raiswell, R. and Plant, J. 1980. The incorporation of trace elements into pyrite during diagenesis of black shales. - Econ. Geology, 75, 684-699.

Wilde, P., Quinby-Hunt, M. S., Berry, W. B. N. and Orth, C. J. 1989. Palaeo-oceanography and biogeography in the Tremadoc (Ordovician) Iapetus Ocean and the origin of the chemostratigraphy of Dictyonema flabelliforme black shales. Geol. Mag., 126, 1, 19-27.

Калласте T. 1990. Поиск структурных индикаторов генезиса осадочных сульфидов железа в отложениях венда, кембрия и ордовика Эстонии. - Изв. АН Эстонин. Геол., 39, 2, 50-59.

Лоог А. 1982. К геохимии постседиментационного минералообразования в граптолитовых аргиллитах тремадока Северной Эстонии. - Уч. зап. Тартуск. ун-та, вып. 527, 116-137.

Пиррус Э. А. 1981. Основные процессы аутигенного минералообразования в терригенных отложениях венда и кембрия Северной Прибалтики. - In: Аутигенные минералы терригенных отложений Прибалтики. Таллинн, 5-24.

Пукконен Э. 1989. Макроэлементы и малые элементы в граптолитовом аргиллите Эстонии. - Горючие сланцы, 6/1, 11-18.

Пылина А. К. 1966. Пиритовые конкреции в диктионемовых сланцах. - Уч. зап. Ленингр. пед. ин-та, 290, 284-230.

Presented by A. Raukas and $\mathrm{K}$. Kauranne

Received June 17,1991

\section{Toivo KALLASTE, Eduard PUKKONEN}

\section{PURIIDIERIMITEST EESTI TREMADOCI ARGILLIIDIS}

Röntgenstruktuurse ja emissioonspektraalse analüüsi andmete põhjal on argilliidis eristatavad vähemalt viis püriiditüüpi. Neist huvitavamad on laialt levinud tsementatsiooniline püriidivorm argilliidiga põimuvates liiva- ja aleuroliidikihtides (tüüp 1) ja tsementatsioonivööndi kontaktidel paiknev õhukesekileline vorm (tüüp 2). Nimetatud vormid on küll lähedase võreparameetri ja kristallisatsiooniastmega, kuid erinevad oluliselt mikroelementide sisalduse, autigeense päevakivi olemasolu ja porsumiskarakteristika poolest. See viitab nende tekketingimuste ja -aja erinevusele. Viimane, kileline vorm peaks olema lähedane argilliidis hajusalt esinevale peendisperssele püriidile, mida uurimiseks eraldi koguda ei õnnestunud.

Ulejäänud püriidivormid on argilliidis enamasti laienenud võre ja halvema kristallisatsiooniastmega, mis on tingitud kas suuremast. mikrolisandite hulgast neis või markasiidi vahefaasi läbimisest. 


\section{О РАЗНОВИДНОСТЯХ ПИРИТА В ТРЕМАДОКСКОМ АРГИЛЛИТЕ (ДИКТИОНЕМОВОМ СЛАНЦЕ) ЭСТОНИИ}

По данным рентгеноструктурного и эмиссионно-спектрального изучения в аргиллите идентифицировано не менее пяти типов пирита. Наиболее распространенным является пирит, цементирующий песчаные и алевролитовые прослои в аргиллите (тип 1). В приконтактовой с ними зоне часто наблюдаются тонкие пленочные выделения пирита (тип 2), которые существенно отличаются от первой разновидности как содержанием микроэлементов, так и присутствием заметных количеств аутигенного ортоклаза и характером выветривания. Эта разновидность близка, по всей вероятности, к тонкорассеянному в аргиллите пириту, выделить который для анализа не удалось. Несмотря на близость основных структурных характеристик этих пиритов, формирование их происходило разными путями: тонкорассеянный (пленочный) пирит образовался за счет компонентов, высвободившихся в самом илистом осадке при диагенезе, цементирующая форма - позднее, за счет компонентов, привнесенных сюда медленно инфильтрующимися водными растворами из вмещающего аргиллита.

Другие разновидности пирнта (типы 3-5) имеют отличную от остальных структуру - расширенную решетку, более низкую степень раскристаллизации, большее количество микропримесей, частую примесь марказита. Особенности их формирования требуют дальнейшего изучения. 